Ophthal. Res. 1973;5:I-V

\title{
Contents, Vol. 5, 1973
}

\section{Contents}

Obenberger, O. and Babický, A. (Prague): Alkali Burns of the Rabbit Cornea.

Corneal Uptake of 14C-Glucose Injected into the Anterior Chamber ... 1

Wallow, I.H.L.; Fine, B.S. and Tso, M.O.M. (Washington, D.C.): Morpho

logic Changes in Photoreceptor Outer Segments Following Photic In

jury. A Comparative Study 10

Stodtmeister, R. (Bad Nauheim): The Spectral Sensitivity Functions of Human

ERG Wavelets 21

Behrens, M. and Manski, W. (New York, N.Y.): Immunogenic Uveitis in Inbred

Rats. Part I 31

Pilkerton, A.R. (Washington, D.C.): Infrared Choroidal Absorption Curves in

Humans. A Technique for Use with Indocyanine Green 41

Van der Eerden, J.J.J.M. and Broekhuyse, R.M. (Nijmegen): Ocular Antigens

III: Localization of Immunogenic Determinants of Structural Glyco-

proteins from Lens Capsule, Corneal Stroma and Sclera in Connective

Tissues of the Eye. An Immunofluorescence and Immunoelectrophoretic

Study 47

Van der Eerden, J.J.J.M. and Broekehuyse, R.M. (Nijmegen): Ocular Antigens

IV: A Comparative Study of the Localisation of Immunogenic Deter

minants of Ocular Structural Glycoproteins in Connective Tissues of

Various Organs

65

Trier, H.G.; Hagemann, H.; Hockwin, O.; Reuter, R., and Geissler, G.

(Bonn): The Determination of Diagnostic Ultrasound Intensities Using

Ammonium Nitrate Solutions

77

Behrens, M. and Manski, W. (New York, N.Y.): Immunogenic Uveitis in In bred Rats. II. Ocular Response to Crystalline and Albuminoid in Lens-

Sensitized Inbred Rats 89

Gartner, J. (Mainz): Fuchs's Epithelioma: Localized amyloidosis of the Ciliary Body in the Aged 102

Ronchi, Lucia and Salvi, G. (Florence): Performance Decrement, under Pro longed Testing, accross the Visual Field 113

Ohrloff, C. and Hockwin, O. (Bonn): Presence of Ketohexokinase EC 2.7.1.3

in Bovine Lenses 121

Behrens, M. and Mansk, W. (New York, N.Y.): Immunogenic Uveitis in Inbred

Rats. 111. Ocular Response to Crystallins and Albuminoid in Normal

Inbred Rats. Relevance to Clinical Lens-Induced Uveitis 129

Condon, P.I. and Hill, D.W. (London): The Testing of Experimental Corneal

Wounds Stitched with Modern Corneo-Scleral Sutures: Experimental 
Corneal Wound Healing. I. Microsurgical and Tensiometric Techniques

and Results 137

IV

Contents

Rothstein, H. and Worgul, B. V. (Burlington, Vt.): Mitotic Variations in the Lens Epithelium of the Frog. II. Possible Role of Temperature and Hor mones 151

Magora, A. and Gonen, B. (Jerusalem): Conditional Computer Analysis of the Onset-to-Onset Duration of Spikes from the Electromyographic Inter ference Pattern of Extraocular Muscles 168 Kaskel, D.; Hockwin, O.; Metzler, Ursula, and Schedtler, Christa-Maria (Bonn): Glycogen Content in the Rabbit Retina in Relation to Blood Circulation 177

Krejëi, L. and Krejcová, H. (Prag): Combined Effects of Corticosteroids and Antiglaucoma Drugs on Corneal Epithelium. A Comparative Tissue Culture Study 186

Magora, A. and Gonen, B. (Jerusalem): Analysis of the Peak-to-Peak and Onsetto-Onset Duration of the Electromyographic Spikes from Extraocular Muscles 193

Gnad, H.D.; Schimmelpfennig, B., and Witmer, R. (Zurich): Observations on the Effect of Steroids on Experimental Uveitis. An Analysis of the Mode of Action of Dexamethasone and Fluorometholone on Ferritin-Induced Uveitis in Rabbits 204

Francois, J.; Victoria-Troncoso, V., and Eeckhout, M. (Ghent): Ftistochemical Studies of Ffyalocytes in Tissue Culture 215

Ohrloff, C; Hockwin, O., and Kaskel, D. (Bonn): Glycogen Metabolism in Bovine Lenses 222

Auricchio, G. and Testa, M. (Palermo): Factors Affecting the Sulphydryl Groups of Structural Proteins of the Lens in Normal and 'Uveitic' Eyes 230 Bhuyan, K.C.; Bhuyan, Durga K., and Katzin, H.M. (New York, N.Y.): Amizol-Induced Cataract and Inhibition of Lens Catalase in Rabbit .. 236 Wilhelmi, E. (Basle): Experimental and Clinical Investigation of a Non-Hormonal Anti-Inflammatory Eye Ointment 253

Francois, J.; Victoria-Troncoso, V. and Eeckhout, M. (Ghent): The Micromorphology of Hyalocytes in Tissue Culture 290

Sayegh, F.; Azmoun, A. and Weigelin, E. (Bonn): Critical Comparison of Vasotonometric (Réthy) and Ophthalmodynamometric Measurements 300 Adachi-Usami, Emiko. and Kellermann, F.-J. (Bad Nauheim): Spatial Summa tion of Retinal Excitation as Obtained by the Scotopic VECP and the Sensory Threshold 308

MacKeen, D.; Fine, S. and Fine, B.S. (Washington, D.C.): Production of Cataacts in Rabbits with the Ultraviolet Laser. A Preliminary Report 317 Saari, M.; Johansson, G. and Huhtala, A. (Helsinki): Myelinated Nerves of the Guinea Pig Iris 325 
Krueger, H.; Moser, E.A. and Zrenner, E. (Munich): Influence of Defocussing on Retinal Images of Test Patterns Calculated with the Modulation

Transfer Function 331

Taillebourg, O.; Payrau, P.; Pouliquen, Y. and Faure, J. P. (Paris): Corneal Cryopreservation. A Histological and Electronmicroscopic Study of Cryopreserved Corneal Endothelium before and after Homografting .. 342

Contents $\mathrm{V}$

Levett, J. (Chicago 111.): Nonlinear Behavior in the Frequency Response of the

Rabbit Retina 353

Cejková, Jitka and Bolková, Alena (Prague): Acid Mucopolysaccharides in Non-

Swelling Dogfish Corneas. Histochemical and Biochemical Study 362

Short Communications Maione, M. and Carta, F. (Parma): Acid Phosphatase and Leucine arylamidase in

Calf and Bovine Lenses

62

Rassow, B. (Hamburg): Beam Guide System of an Argon Laser Coagulator ....

Subject Index 371

Authors' Index 374

Contents to Vol. 5 after 374 